Abstract

\title{
Some Wild Edible Mushroom Anticancer Activity Against Prostate Cell Lines ${ }^{\dagger}$
}

\author{
Hatice Bekci ${ }^{1, *}$, Mustafa Cam ${ }^{2}$ and Ahmet Cumaoglu ${ }^{3}$ \\ 1 Vocational Sciences, Kayseri University, 38039 Kayseri, Turkey \\ 2 Department of Food Engineering, Faculty of Engineering, Erciyes University, 38039 Kayseri, Turkey; \\ mcam@erciyes.edu.tr \\ 3 Faculty of Pharmacy, Erciyes University, 38039 Kayseri, Turkey; ahmetcumaoglu@erciyes.edu.tr \\ * Correspondence: haticebekci@kayseri.edu.tr; Tel.: +90-543-500-29-87 \\ + Presented at the 3rd International conference on Natural Products for Cancer Prevention and Therapy, \\ Kayseri, Turkey, 18-20 December 2019.
}

Published: 31 December 2019

\begin{abstract}
Prostate cancer is one of the cause of mortality and morbidity in men. High nutritional quality mushrooms have been consumed as food for a long time and Thanks to their bioactive components, they can be used in many fields such as pharmaceuticals, cosmetic products, dietary supplements and functional food production. The purpose of the research was to evaluate these derivatives against in vitro to obtain novel specific and effective anticancer agents against prostate cancer. In the study, Amanita caesarea, Sparassis crispa, Lepista nuda, Auricularia auricula, Tricholoma terreum and Lentinus tigrinus fungi were used. Anticancer activities of the compounds were evaluated in vitro by using MTT method against PC-3 and DU-143 (androgen-independent human prostate cancer cell lines) prostate cancer cell lines. Cisplatin was used as the positive sensitivity reference standard. The most effective among these fungus species biological activity against PC3 cancer cell line $\left(\mathrm{IC}_{50}=327.34 \mu \mathrm{M}\right)$, against DU-145 $\left(\mathrm{IC}_{50}=459.19 \mu \mathrm{M}\right)$.
\end{abstract}

Keywords: mushroom; anticancer; prostate cell line

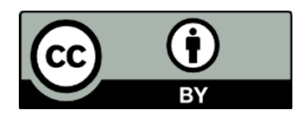

(C) 2019 by the authors. Licensee MDPI, Basel, Switzerland. This article is an open access article distributed under the terms and conditions of the Creative Commons Attribution (CC BY) license (http://creativecommons.org/licenses/by/4.0/). 